\title{
Toward Probiotict Food Product from Meat Through Isolation and Identification Lactic Acid Bacteria As Probiotic Culture Stater
}

\author{
Yunilas $^{\#}$, Lili Warly ${ }^{*}$, Edi Mirwandhono ${ }^{\#}$

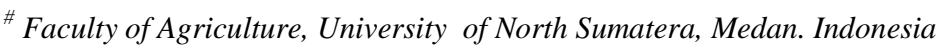 \\ E-mail: yunilas11@yahoo.co.id \\ * Faculty of Animal Husbandry, University of Andalas, Padang. Indonesia
}

\begin{abstract}
Probiotic food products of meat can provide extensive benefits, to increase the shelf life and nutritional value also improve the taste. The use of lactic acid bacteria culture (LAB) derived from the isolation of the meat and the addition of probiotic cultures (Lactobacilli and Bifidobacteria) in fermented sausage processing is expected to produce a probiotic sausage products with nutritional value, and better shelf life and improve health. This study aimed to isolate and identify lactic acid bacteria (LAB) of meat as a starter culture fermented sausages. The parameters observed were gram test, catalase, motility, gas production, type of fermentation, growth at various temperatures and $\mathrm{pH}$. The results were obtained 28 isolates, 17 isolates were able to produce acid and 8 of them are lactic acid bacteria (LAB) with the characteristics of gram-positive, catalase negative, not motile, produces gas, are hetero and homo fermentative, optimum growth temperature of $300 \mathrm{C}$ and a few of them are able to grow on pH 3.5. Lactic acid bacteria that able to be combined with probiotics as sausage starter culture to the probiotic food products of meat.
\end{abstract}

Keywords - Food probiotics, lactic acid bacteria, sausage, probiotics.

\section{INTRODUCTION}

Meat as a source of animal protein that is highly appreciated by the public in addition to other farm commodities. Today the demand for processed products derived from meat farms continues to increase as sausages, naget, cornet etc. Pergesernya the consumption patterns of eating fresh meat into processed products ready to eat pushing for the development of technology in meat processing. There are various ways of processing of meat that can be developed to improve the nutritional value and the power shelf. One of processed meat products of fermentation is sausage of fermentation

Sausage is one of the fermented meat products by using starter culture microorganisms. This starter can consist of one or more types of microorganisms. Fermented sausages have better benefits when compared to other processed meats. The fermentation process in the processing of a treatment process using microorganisms activity in a controlled manner so as to make the culture strain induces specific enzyme activity to modify the substrate. This change will eliminate a potential substrate pathogenic microorganisms. The result of this fermentation can increase the shelf life (durability of the produced acid), increase the nutritional value and taste (produce products with the characteristics typical flavor and aroma). BAL is able to convert sugars (including lactose) and other carbohydrates into lactic acid. This not only provides a unique sour taste of fermented dairy food such as fermented milk, but also act as providers by reducing the $\mathrm{pH}$ and create opportunities harmful organisms to grow less. Similarly, the fermented meat products.

The process of fermentation in the sausage can be naturally occurring lactic acid bacteria (LAB) are present in the flesh, but has a weakness that the population and the type of lactic acid bacteria contained in fresh meat is difficult to control. If the beginning number of lactic acid bacteria little, then decrease in $\mathrm{pH}$ will be slow so that spoilage bacteria and pathogens evolve. The addition of lactic acid bacteria can be carried out in making sausage of fermentation, the fermentation process will take place so that a uniform and easily controlled (1).

The use of bacteria strains producer bacteriocin as starter cultures or protective cultures, lately many developed and able to controlling the presence of pathogens and spoilage bacteria in food products ready to eat (2). Culture is often used for the fermentation of meat and commercially available is derived from Streptococcus group (3), Micrococcus group (4), piantarum Lactobacillus, 
Lactobacillus sake, L. Curvatus, Pediococcus iacidactici and the right combination with P. Pentosaceus (5) and (6). In Indonesia, Lactobacillus plantarum is found in many traditional sausage from Bali (order) (7).

Starter culture in making of sausages can be divided into two categories. The first generation contains lactic acid bacteria derived from plant material. The second generation derived from meat material is specifically adapted to the ecology of meat fermentation (8). Starter cultures of lactic acid bacteria isolated from meat other than still less adaptive and less than optimal for meat fermentation is characterized by fluctuating viability during the process (7) and (9).

To be fermented meat can provide extensive benefits in addition to increase the shelf life and high nutritional value is also expected to act as a probiotic that helps launch the digestive system and the immune system by increasing the amount of good bacteria in the digestive tract so that it can improve health it is necessary to be studied (studied) use some cultures of lactic acid bacteria from meat and the use of cultural isolation that has the ability as a probiotic.

Probiotics are live bacteria that are given as a food supplement that has a beneficial effect on human and animal health, by improving the balance of intestinal microflora. Microflora were classified as probiotics are lactic acidproducing mainly Lactobacilli and Bifidobacteria on the classes. Thus, the use of lactic acid bacteria culture (LAB) derived from fresh meat itself and the addition of probiotic cultures in fermented meat processing is expected to produce fermented meat products (sausages) with nutritional value and good shelf life and can improve your health so that the resulting product final form of probiotics Food origin of meat.

\section{RESEARCH METHODOLOGY}

\section{A. Materials Research}

Materials used include fresh meat obtained from traditional markets, namely the market in Medan Simpang Lemonade, media de ROGOSA Sharpe broth (MRSB) and de Man ROGOSA Sharpe agar (MRSA), Buffer Peptone Water (BPW), NA media, Plate Count Agar (peptone, yeast extrax, D-Glucose, order), CaCO3, Brom Creasol Purple (BCP), sulfite indole multility (SIM). The material for Gram stain (methylene blue, filter paper, crystal violet, ethanol, lugol, acetone alcohol, safranin), aquadestila, $\mathrm{NaCl}$, hydrogen peroxide.

\section{B. Research Methods}

Isolation of Lactic Acid Bacteria. Isolation is done by the method of (10). Isolation made of two different conditions, namely 12 hours postmortem (A) and $24 \mathrm{~h}$ postmortem (B). $10 \mathrm{~g}$ of each sample was taken and added to $90 \mathrm{ml}$ of sterile diluent containing $0.1 \% \mathrm{BPW}$ then homogenized for 30 seconds. Dilution is done to 108; performed on MRSA isolation media (streak plate method) containing $1 \% \mathrm{CaCO} 3$ and BCP $60 \mathrm{ppm}$ were incubated at $37^{\circ} \mathrm{C}$ for $48 \mathrm{~h}$. The culture was purified by repeated streaking. Pure culture on agar slant stored at a temperature of 40C MRS for shortterm use. Selection is done by morphological observation (using a microscope).
Identification of LAB isolates according to (11); (12) and (13) includes several tests: 1) Gram staining test performed using Gram's staining method; 2) catalase test, catalase test is done by adding 1-2 drops of hydrogen peroxide $3 \%$ in preparations that had been smeared by the LAB isolates. Air bubbles are formed indicating a positive LAB against catalase test; 3) motility test, this test is done by inoculating isolates of LAB on upright semi-solid media (sulfite multility indole) were incubated for 48 hours at $30 \mathrm{oC}$. Form of spreading colonies on semi-solid media showed up motile bacteria; 4) $\mathrm{CO} 2$ production test, testing for $\mathrm{CO} 2$ production can be done by inoculating isolates of LAB in MRS liquid medium in a test tube in which there are the Durham tube. BAL incubated for 5 days at $30 \mathrm{oC}$. Then observed that there are air bubbles in the Durham tube. Air bubbles are formed indicating a positive test to the production of $\mathrm{CO} 2 ; 5$ ) growth at various $\mathrm{pH}$ test, this test is done by observing the growth of LAB isolates at $\mathrm{pH} 3.5$ and 9;6) test the growth at various temperatures, this test is done by observing the growth of LAB isolates at a temperature of $10^{\circ} \mathrm{C}, 30^{\circ} \mathrm{C}$ and $450 \mathrm{C}$. Pure cultures have been obtained replanted (refresher). Refresher culture done by growing isolates on media with long MRSB $24 \mathrm{~h}$ incubation at $37^{\circ} \mathrm{C}$. Refresher continue until the culture to adapt to life in the media and is quite a lot that is characterized by the presence of turbidity in the growth media. Refresher culture intended to update and expand the population of lactic acid bacteria culture before being used as a starter culture fermented sausages.

\section{RESULTS AND DISCUSSION}

\section{A. Isolation of Lactic Acid Bacteria From meat}

From the results of isolation beef with 2 conditions acquired 14 isolates derived from 12 hours post-mortem and 14 isolates from 24 hours post mortem. Of the 28 isolates were successful acquired only 17 indicated as acidproducing bacteria with characterized by the discovery of isolates the yellow color on MRS medium supplemented For BCP.
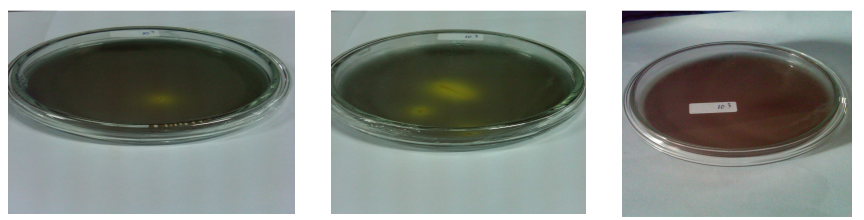

Fig.1 Ability of isolates to produce acid in MRS medium BCP

From the 17 isolates carried several acid-test to determine the characteristics and identify bacteria that produce lactic acid. Characteristics and identification include Gram stain, catalase test, motility test, gas production test, the type of fermentation, growth tests at various $\mathrm{pH}$ and temperature (Table 1).

\section{B. Characteristics of Lactic Acid Bacteria}

1) Gram Staining (Gram's Staining): Gram's staining performed at the age of 24-hour bacterial cultures were grown on MRS agar media. Staining is done in addition to knowing gram of bacteria can also determine the shape and arrangement of cells of lactic acid bacteria by observation 
under a microscope at 1000x magnification. The observation that the 17 isolates obtained by acid-producing bacteria are gram-positive bacteria with the form of rods (bacilli) and spherical (cocci) (Table 1).

2) Catalase Test: Catalase test is done by dropping + 2 drops of $\mathrm{H} 2 \mathrm{O} 23 \%$ at the age of 24-hour bacterial culture. Positive test reaction when bubbles are formed which means there is the formation of oxygen gas $(\mathrm{O} 2)$ as a result of breakdown of $\mathrm{H} 2 \mathrm{O} 2$ by catalase enzyme produced bacteria. Of the 17 acid-producing isolates, 8 isolates showed catalase-negative results (Table 1). Asam lactic bacteria is bacteria with negatif catalase (14).

3) Motility test: Motility test done by inoculating bacteria isolates in an upright semi-solid media (sulfite multility indole) were incubated for 48 hours at $30 \mathrm{oC}$. Motility is determined on the basis of least average growth of bacteria on the media. Motile bacteria are not only limited growth in needle scratches. Of the 17 acidproducing isolates, 10 isolates showed negative results motility (Table 1).
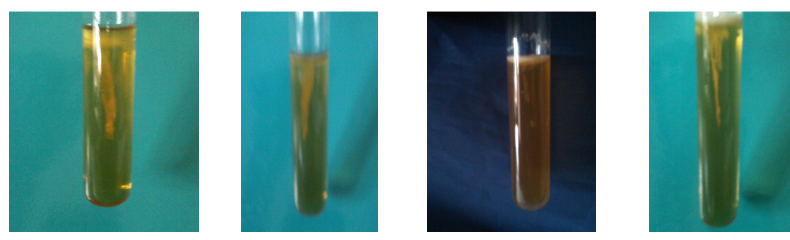

Fig. 2 Motility test of lactic acid bacteria

4) Test Gas Production: $\mathrm{CO} 2$ production test, testing for $\mathrm{CO} 2$ production can be done by inoculating isolates of LAB on MRS broth liquid medium in a test tube in which there are the Durham tube. LAB incubated for 5 days at $30 \mathrm{oC}$. The test results of the 17 isolates showed acidproducing isolates that are only 7 heterofermentatif characterized by gas in the Durham tube and 10 isolates are homofermentatif (Table 1).

5) Test Growth on Various $\mathrm{pH}$ and Temperature: This test is done by observing the growth of LAB isolates at $\mathrm{pH} 3$ and $\mathrm{pH} 9$ and temperature of $10 \mathrm{oC}$ and $45 \mathrm{oC}$. The results showed that of the eight isolates identified as $\mathrm{BAL}$ not all isolates were able to grow at $\mathrm{pH} 3$ and $\mathrm{pH} 9$ and temperature $100 \mathrm{C}$ and $450 \mathrm{C}$ (Table 2) Based on the test results of 17 isolates from beef production of acid in the 2 conditions was only 8 isolates were identified as Lactic Acid Bacteria that YEL131, YE132, YEL133, YEL231, YEL232, YEL234, YEL242, YEL251 characterized by Gram-positive isolates results, catalase negative, negative motility, shape and rounded stem cells, can be homofermentatif and heterofermentatif. This is supported by the statement of (15), that the criteria for lactic acid bacteria such as gram-positive, catalase-negative, rod-shaped or round and can be homofermentatif or heterofermentatif.

6) Identification of Lactic Acid Bacteria: Identification of bacterial isolates to genera of lactic acid bacteria require major characteristics of bacteria include cell morphology (shape and arrangement of cells), biochemical tests and the type of fermentation (presence or absence of gas production). According (16) test morphology and fermentation type test can be performed to identify the level of genera of lactic acid bacteria (LAB).

TABLE I

TEST OF BIOCHEMISTRY AND PHYSIOLOGICAL OBSERVATIONS ISOLATES OF LACTIC ACID BACTERIA AGE 24 HOURS

\begin{tabular}{|c|c|c|c|c|c|c|c|c|c|c|c|}
\hline \multirow[b]{2}{*}{ isolat } & \multirow[b]{2}{*}{ Gram } & \multirow[b]{2}{*}{$\begin{array}{c}\text { Cell } \\
\text { shape }\end{array}$} & \multirow{2}{*}{$\begin{array}{c}\text { Gas } \\
\text { product } \\
\text { ion } \\
\left(\mathrm{CO}_{2}\right)\end{array}$} & \multirow{2}{*}{$\begin{array}{l}\text { cat } \\
\text { ala } \\
\text { se }\end{array}$} & \multirow{2}{*}{$\begin{array}{l}\text { mo } \\
\text { tili } \\
\text { ty }\end{array}$} & \multirow{2}{*}{$\begin{array}{l}\text { Type of } \\
\text { ferment } \\
\text { ation }\end{array}$} & \multicolumn{3}{|c|}{$\begin{array}{l}\text { Growth } \\
\text { subu (C) }\end{array}$} & \multicolumn{2}{|c|}{ GrowthpH } \\
\hline & & & & & & & 10 & 30 & 45 & 3,5 & 9 \\
\hline $\mathrm{YEL}_{[3 !}$ & +1 & bacilli & + & . & - & hetero & . & + & . & . & . \\
\hline $\mathrm{YEL}_{132}$ & + & cocci & - & . & . & homo & . & + & . & . & . \\
\hline $\mathrm{YEL}_{1,33}$ & + & bacilli & . & $\cdot$ &. & homo & . & + & + & . & . \\
\hline $\mathrm{YEL}_{231}$ & + & $\operatorname{cocc}$ & + & . & . & hetero & . & + & . & . & . \\
\hline $\mathrm{YEL}_{232}$ & + & $\operatorname{cosci}$ & - & $\cdot$ &. & homo & . & + & . & + & . \\
\hline $\mathrm{YEL}_{234}$ & + & cocci & + & . & . & hetero & . & + & . & . & . \\
\hline $\mathrm{YEL}_{242}$ & + & $\operatorname{cosci}$ & - & $\cdot$ &. & homo & . & + & + & . & . \\
\hline YELse & + & $\operatorname{cocci}$ & . & . & . & homo & . & + & + & - & . \\
\hline
\end{tabular}

From the above observations can be specified kind or type genus of lactic acid bacteria isolated from beef at 12 hours and 24 hours after the post mortem. The lactic acid bacteria found in this study include the genus Laktobacillus, Pediococcus, Leuconostoc, Streptococcus/Enterococcus.

7) Genera of Lactobacillus: Lactic acid bacteria isolates from beef that is classified in the genus Lactobacillus isolates with YEL131 and YEL133 code with the following characteristics: gram positive bacillus cell shape, catalase negative, negative motility, is heterofermentatif and homofermentatif, white colony color and colony edge entire and facultative anaerobic. From the description above characteristics can be identified that bacteria isolates YEL.131 and YEL.133 including the genus Lactobacillus heterofermentatif and Lactobacillus homofermentatif.

Lactobacillus bacteria including Gram + , not sporulating, not motile, facultative anaerobic, microaerophilic sometimes, little grown up in the air but great on the circumstances under low oxygen tension, and several anaerobes in isolation (17) (14) states, there are homofermentatif Lactobacillus and heterofermentatif. Colonies on agar media usually $2-5 \mathrm{~mm}$, convex, entire, opaque (opaque) and without pigment, kemoorganotrof, metabolism is fermentative and saccharoclastic. A little of half the carbon end product is lactate, does not produce nitrate, gelatin does not become liquid, cytochrome negative, catalase negative and oxidase positive. Growing optimum temperature of 30-400C. Lactobacilli are widespread in the environment, especially in animal and vegetable food products. They normally inhabit the intestinal tract of birds and mammals, and mammals as well as non-vaginal pathogens.

8) Genera of Leuconostoc: Lactic acid bacteria isolates from beef that is classified in the genus Leuconostoc isolates YEL231 and YEL234. Characteristics and the nature of the identification of lactic acid bacteria are gram-positive $(+)$, cocci cell shape, catalase negative, motile negative, is heterofermentatif, positive gas production, milk 
white colony color, colony edges entire, clear color pigments, and cell properties facultative anaerobes.

(14) stated that the genus Leuconostoc round or cocci in pairs, chain, catalase-negative, gram-positive, heterofermentatif, non-motile, non-spore producing, facultative anaerobic, small colonies on culture growth occurs along the straight jab and little on the surface, the optimum temperature of 20 to $300 \mathrm{C}$, non-proteolytic, resistant to high salt concentrations, fermentation started quickly thus inhibit unwanted bacteria that grow during fermentation.

TABEL II

CHARACTERISTICS OF LAB ISOLATES INTO GENERA

\begin{tabular}{|c|c|c|c|c|c|c|}
\hline Karakteristik & \multicolumn{6}{|c|}{ Isolat BAL } \\
\hline & Standar & $\mathrm{YEL}_{13 !}$ & $\mathrm{YEL}_{133}$ & Standar & $\mathrm{YEL}_{231}$ & $\mathrm{YEL}_{234}$ \\
\hline Gram & + & + & + & + & + & + \\
\hline Btk sel & Batang & Batang & Batang & Bulat & Bulat & Bulat \\
\hline Katalase & - & . & e & ( & - & . \\
\hline Motilitas & - & $\cdot$ & $\cdot$ & - & - & - \\
\hline Prod gas & +1. & + & $\cdot$ & + & + & + \\
\hline Tipe ferments & $\begin{array}{c}\text { Hetero hom } \\
0\end{array}$ & Hetero & Homo & Hetero & Hetero & Hetero \\
\hline Ptbhsuhu $10^{\circ} \mathrm{C}$ & +1. & - & - & +1. & - & - \\
\hline Ptbh suhu $45^{\circ} \mathrm{C}$ & +1. & - & + & - & - & - \\
\hline Ptbh suhu $30^{\circ} \mathrm{C}$ & & + & + & & + & + \\
\hline Pabh pH 3,5 & $+/$. & t & . & $+\%$ & - & + \\
\hline
\end{tabular}

9) Genera of Pediococcus: Lactic acid bacteria isolates from beef that is classified in the genus Pediococcus isolates YEL132, YEL YEL 242 and YEL 251 with the following characteristics: gram positive cocci cell shape, negative catalase, negative motility, is homofermentatif, facultative anaerobic.

10) Genera of Streptococcus: Lactic acid bacteria isolates from beef that is classified in the genus Streptococcuss YEL232 isolates with the following characteristics: gram positive, cocci cell shape, negative catalase, negative motility, is homofermentatif, facultative anaerobic.

TABEL III

CHARACTERISTICS OF LAB ISOLATES INTO GENERA

\begin{tabular}{|l|c|c|c|c|c|c|}
\hline \multirow{2}{*}{ Karakteristik } & \multicolumn{7}{|c|}{ Isolat BAL } \\
\cline { 2 - 7 } & $\begin{array}{c}\text { Stand } \\
\text { ar }\end{array}$ & $\begin{array}{c}\text { YEL }_{13} \\
2\end{array}$ & YEL $_{242}$ & YEL $_{251}$ & $\begin{array}{c}\text { Stand } \\
\text { ar }\end{array}$ & $\begin{array}{c}\text { YEL } \\
232\end{array}$ \\
\hline Gram & + & + & + & + & + & + \\
\hline Btk sel & Bulat & Bulat & Bullat & Bulat & Bulat & Bullat \\
\hline Katalase & - & - & - & - & - & - \\
\hline Motilitas & - & - & - & - & - & - \\
\hline Prod gas & - & - & - & - & - & - \\
\hline Tipe ferments & Homo & Homo & Homo & Homo & Homo & Homo \\
\hline Ptbh suhu 10 ${ }^{\circ} \mathrm{C}$ & $+/-$ & - & - & - & $+/-$ & - \\
\hline Ptbh suhu 45 ${ }^{\circ} \mathrm{C}$ & $+/-$ & - & + & + & $+/-$ & \\
\hline Ptbh suhu 30 ${ }^{\circ} \mathrm{C}$ & & + & + & + & & + \\
\hline Ptbh pH 3,5 & - & - & - & - & $+/-$ & + \\
\hline Ptbh pH 9 & - & - & - & - & $+/-$ & - \\
\hline Genus & \multicolumn{7}{|c|}{ Pediococcus } \\
\hline
\end{tabular}

\section{CONCLUSIONS}

From the results acquired bacteria that have the ability to produce lactic acid with characteristics: gram-positive, rodshaped or spherical, catalase negative, not motile and metabolism generally produce lactic acid as its main product.
Lactic acid bacteria include Lactobacillus YEL.131 obtained, YEL.133 Lactobacillus, Leuconostoc YEL.231, YEL.234 Leuconostoc, Pediococcus YEL.132, Pediococcus YEL.242, Pediococcus YEL.251, Streptococuucs YEL.232. Lactic acid bacteria obtained can be combined with the probiotic Bifidobacteria as sausage starter culture to the probiotic food products from meat.

\section{ACKNOWLEDGMENT}

This research was supported by Grant from Directorate General Higher Education (Dikti) Kemendiknas of Republic Indonesia.

\section{REFERENCES}

[1] Hui, Y.H., W.K. Nip., R.W. Rogers, and O.A. Young. 2001 Meat Science and Application. Marcel Dekker Inc. New York, USA

[2] Hugas, M., M.Garriga, T. Aymerich, and JMMontfort, 1995 Inhibition of Listeria in dry fermented sausages by the bacteriocinogenic Lactobacillus sake CTC494. J. Appl. Bacteriol. 79, 322- 330.

[3] Fardiaz, S. 1992 Analysis of Food Microbiology. University Centre of Food and Nutrition, Bogor Agricultural University, Bogor

[4] Varnam, A. N. \& J. P. Sutherland. 1995 Meat and Meat Products. Chapman and Hall, London

[5] Erdo TM rul, O.T., OD. Cetin, and O. Ergun. A 2002 study on Metabolic and Antimicrobial Activities of Pediococcus pentosaceus Isolated from Fermented Sausage. Pakistan J. of Biological Sciences. 5 (5): 594-596.

[6] Bromberg, R., I. Moreno, c.L. Zagagini, R.R. Delboni, and J. de Oliveira. 2004 Isolation of bacteriocin-producing lactic acid bacteria from meat and meat products and its spectrum of inhibitory activity. Brazilian J. Microbiology 35: 137-144.

[7] Arief, I.I., R.R.A. Maheswari and T. Suryati. 2003, and Beef pengempu Dark Firm Dry (DFD) Through Fermentation Technology By Lactic Acid Bacteria Lactobacillus plantarum. Basic Research Report. Bogor Agricultural University, Bogor.

[8] Hugas, M. and J.M. Monfort. 1997 Bacterial Starter Cultures For Meat Fermentation. Food Chemistry. (59) 4: 547-554.

[9] Hapsari, D., L. IRAWATI, Irfan and S. Pratt. 2003 Beef Quality Improvement Microbiology Dark Firm Dry (DFD) Through Fermentation Process Using Starter Culture Lactobacillus plantarum. Research Report PKM. Bogor Agricultural University, Bogor.

[10] Ogunbanwo, S.T., A.l. Sanni, A.A. Onilude. 2003 characterization of Lactobacillus plantarum bacteriocin Produced by Lactobacillus brevis OG1 and F1. African J.o. Biotechnology. 2 (8): 219-227

[11] Prescott, LM, Harley, JP and Klein, DA, 2005, Microbiology, 6th Edition, Mc. Graw-Hill, Boston. Tamang et al., 2005, Identification of Lactic Acid Bacteria Isolated predominant from Traditionally Fermented Vegetable Products of the Eastern Himalayas, International Journal of Food Microbiology, 105, 356347

[12] Waluyo, L., 2008, Basic Methods in Engineering and Microbiology, University of Malang Press, Malang.

[13] Tamang et al., 2005, Identification of Lactic Acid Bacteria Isolated predominant from Traditionally Fermented Vegetable Products of the Eastern Himalayas, International Journal of Food Microbiology, $105,356347-$.

[14] Stamer,J.R. 1979. The Lactic Acid Bacteria. Microbes of Diversity. J. Food Technol. 1:60-65

[15] Wood,B.J.B. 1992. The Lactc Acid Bacteria in Health and Deseases. London: Blackie Academic and Professional.

[16] Rahayu,E.S., and Margiono,.S. 1997. Bakteri Asam Lactat: Isolasi dan Identifikasi. Materi Workshop. PAU Pangan dan Gizi, Universitas Gadjah Mada. Yogyakarta, 13-14 Juni 1997.

[17] Holt,J.G. Krieg, N.R. Sneath. P.H.A. Staley, JT and William S.T 1994. Bergey's Manual of Determinative Bacteriology. Ninth Edition. Baltimor. Maryland. USA. Williams and Wilkins. 